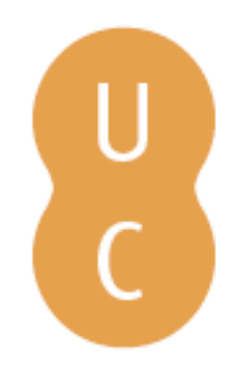

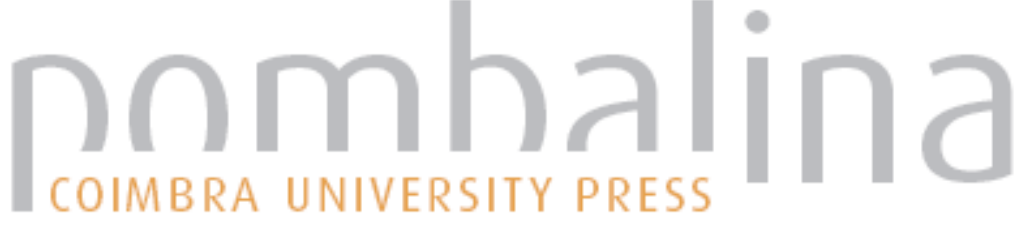

\section{New method of forecasting forest fire risk in Poland}

Autor(es): $\quad$ Kwiatkowski, Mirosaw; Szczygie, Ryszard; Koakowski, Bartomiej

Publicado por: Imprensa da Universidade de Coimbra

URL

persistente:

URI:http://hdl.handle.net/10316.2/34352

DOI:

DOI:http://dx.doi.org/10.14195/978-989-26-0884-6_133

Accessed : $\quad$ 26-Apr-2023 09:17:41

A navegação consulta e descarregamento dos títulos inseridos nas Bibliotecas Digitais UC Digitalis, UC Pombalina e UC Impactum, pressupõem a aceitação plena e sem reservas dos Termos e Condições de Uso destas Bibliotecas Digitais, disponíveis em https://digitalis.uc.pt/pt-pt/termos.

Conforme exposto nos referidos Termos e Condições de Uso, o descarregamento de títulos de acesso restrito requer uma licença válida de autorização devendo o utilizador aceder ao(s) documento(s) a partir de um endereço de IP da instituição detentora da supramencionada licença.

Ao utilizador é apenas permitido o descarregamento para uso pessoal, pelo que o emprego do(s) título(s) descarregado(s) para outro fim, designadamente comercial, carece de autorização do respetivo autor ou editor da obra.

Na medida em que todas as obras da UC Digitalis se encontram protegidas pelo Código do Direito de Autor e Direitos Conexos e demais legislação aplicável, toda a cópia, parcial ou total, deste documento, nos casos em que é legalmente admitida, deverá conter ou fazer-se acompanhar por este aviso. 


\section{ADVANCES IN}

Forest Fire

\section{RESEARCH}

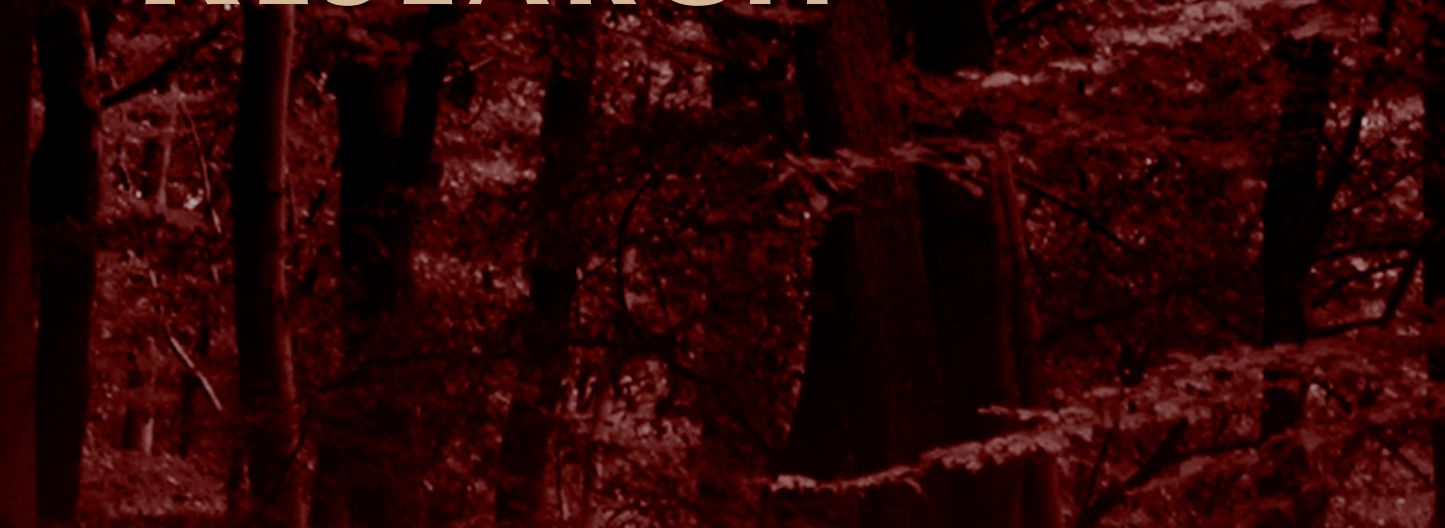

\section{DOMINGOS XAVIER VIEGAS}

\section{EDITOR}




\title{
New method of forecasting forest fire risk in Poland
}

\author{
Mirosław Kwiatkowski, Ryszard Szczygieł, Bartłomiej Kołakowski \\ Forest Research Institute. Sękocin Stary, 3, Braci Leśnej Street, 05-090 Raszyn, Poland. \\ r.szczygiel@ibles.waw.pl, m.kwiatkowski@ibles.waw.pl, b.kolakowski@ibles.waw.pl
}

\begin{abstract}
The possibility of reducing losses caused by forest fires, apart from preventative activities, should be sought primarily in limitation of the area burnt as a result of fires. This objective may be achieved through optimisation of extinguishing activities. The basic requirement of such activities is accurate forecasting of forest fire risk depending on meteorological and physical conditions in forests. The purpose of the research was to prepare a new method of forecasting forest fire risk, which would enable a more precise method of evaluation of the risk of an outbreak of fire in relation to existing and forecast meteorological conditions in forests.

Establishing provisional assumptions of the new method accepted:

- possibility of determining actual fire risk,

- possibility of forecasting forest fire risk for the afternoon hours in the morning hours of the given day and the following day,

- possibility of forecasting the moisture content of pine litter (Pinus silvestris L.),

- preparation of a method enabling limitation of fire prevention system operating costs.

To enable drawing up a fire risk forecast (in the morning for the hours of the afternoon and the following day) formulae were drawn up equally enabling calculation of predicted moisture content of pine litter on the basis of its actual current values and forecast meteorological values. The basis for assessment of the proposed method were data relating to the frequency of occurrence of particular degrees of risk, average number of fires in forecast zone depending on the degree of risk and also the average area of fire at the given degree.

The drawn up method is based on moisture measurements of flammable material, which has a significant relationship to its precision. Selection of test material - pine litter is adjusted to the specific conditions occurring in the majority of pine stands (Pinus silvestris L.) in Poland. As a result of the work it was possible to create a prognosis method enabling precise establishment of the fire risk in forests according to the accepted assumptions. The results obtained during testing of this method indicate a high accuracy in forecasting fire risk and a satisfactory precision of formulae for calculating moisture content of litter. On this basis it may be stated that the drawn up method enables a decidedly better means to define the actual fire risk, simultaneously providing its forecast for later hours and it is currently introduced for application in fire protection of Polish forests. Such a solution may bring about a significant limitation of fire protection operating costs in forests and facilitate organisation of the work of the services responsible for it.
\end{abstract}

Keywords: Forecasting fire risk, forest fires, moisture of flammable material

\section{Introduction}

Permanent increase of fire risk, the effect of which is the increasing number of fires and area burnt and also the increasing operating costs of the fire prevention system were the stimuli to undertake research intended to limit fire losses. The possibility of reducing losses, apart from prevention activities, should be sought primarily in limiting the surface area burnt as a result of fires. This objective may be achieved by optimising fire extinguishing activities. The basis for this is accurate forecasting of fire risk of forest based on meteorological and physical conditions prevailing in the forest. This information enables specification of the required state of operational readiness of the services responsible for forest fire prevention. 
The objective of the research was the drawing up of a new method of forecasting the risk of forest fire, which enables a more precise means of evaluation of the risk of occurrence of fire in relation to actual and forecast conditions in forests.

The basis for evaluation of conditions of the occurrence of fires in forests was data of the National Forests from the years 2002-2008. This analysis equally included the occurrence of fires in relation to stand conditions, types of fires, temporal analysis of occurrence in particular months and times of day, as also the occurrence of fires in relation to meteorological conditions.

\section{Methods and results}

On the basis of this analysis it may be clearly seen, that most of the frequently burning stands are pine of a young age class growing in coniferous habitats. The decided majority of them are fires of the soil covering, which constitutes $85.5 \%$ of the general number of fires. The majority of fires occur from March to September, and the most, close to 25\% occur in April. Approximately $70 \%$ of all fires in total occur between the hours of 11.00 and 19.00 . Whereas the greatest intensity $-10.7 \%$ occurs at the hour of 15.00. (figure 1)

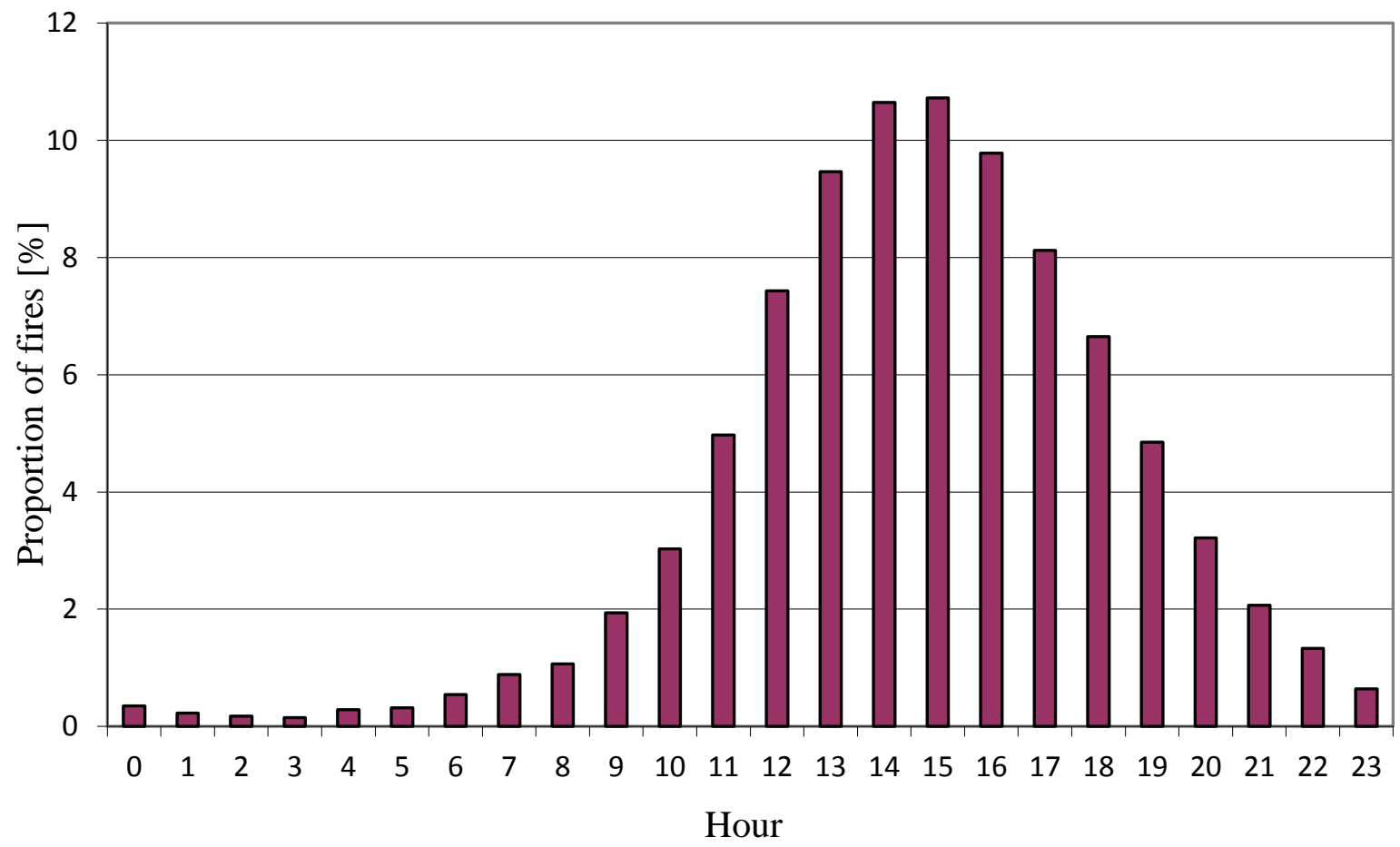

Figure 1. Occurrence of forest fires depending on the time of day

In the analysis of occurrence of fires in relation to meteorological conditions and moisture of litter 25,000 fires were considered. It consisted primarily of evaluation of the number of fires in relation to the values of these parameters. In the analysis of this value from the hour of 9.00 in relation to fires, this occurred between the hours of 9.00 and 13.00. The dependency of the occurrence of fires on the given parameter may be characterised by the frequency of occurrence of fires, being in relation to the number of occurrences of the given value of this parameter. In figure 2 is presented an example schedule of frequency of occurrence of fires depending on moisture of litter as also is presented the expected schedule and the strength of the connection between observed and expected values expressed as a value of the coefficient of determination and $\mathrm{R} 2$. 


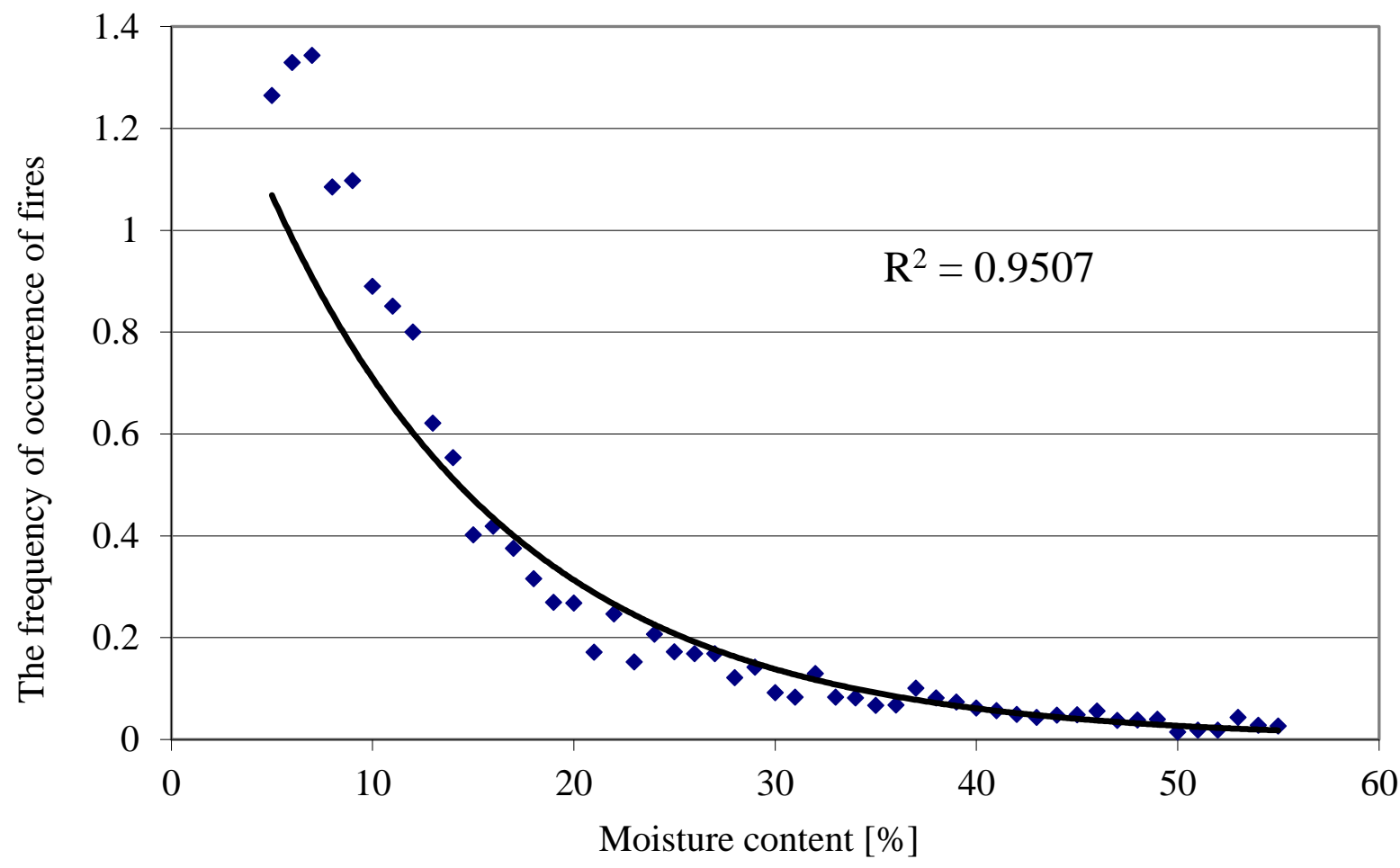

Figure 2. Frequency of occurrence of fires after the hour 13.00 in relation to moisture content of litter at 13.00

Establishing provisional assumptions of the new method included:

- possibility of determining actual risk of fire for given area, being the average for all measurement points located on the terrain equally those in which the moisture content measurement of litter has not been performed.

- possibility of forecasting the risk of forest fire for the afternoon in the morning hours of the given day,

- possibility of forecasting fire risk for the following day,

- forecasting moisture content of litter for the afternoon and of the given day and for the following day,

- drawing up a method enabling limitation of operational costs of fire prevention system.

All analyses of occurrences of fires in relation to the above-mentioned parameters were performed using the reverse step multiple regression method. On this basis polynomials enabling establishment of fire risk for particular points were calculated. In order to standardise the principles of defining the degree of fire risk from the values of polynomials particular formulae were converted in such a manner that the specified degree of fire risk from the value of polynomial of particular formulae were converted in such a way that the specified range of polynomial values always corresponded to the same degree of fire risk. Depending on the values thus calculated for the polynomial, it is possible to establish the degree of fire risk for the given point.

Polynomial risk for forecast point at the hour of 9.00

Polynomial_forecast_09 $=\mathbf{f}_{\text {(TP_09, WP_09, OP_09, wS_09) }}$

Polynomial risk of forecast point at 13.00

Polynomial_forecast_13 $=f_{\text {(TP_09, WP_09, WS_09, TP_13, WP_13) }}$ 
Polynomial risk for forecast point at 13.00 with regard to moisture content of litter at 13.00

Polynomial_forecast_13P $=\mathbf{f}_{(\text {TP_09, WP_09, OP_09, WS_09, TP_13, WP_13, WS_13) }}$

Polynomial risk for auxiliary point at 9.00

Polynomial_measurement_09 $=\mathbf{f}$ (WP_09, WS_09P)

Polynomial risk for auxiliary point at 13.00

Polynomial_measurement_13 $=$ f ( WP_09, TP_13, WP-13, TP_09P, WP_09P, WS_09P, WP_13P)

where:

TP_09 - air temperature at 9.00,

TP_13 - air temperature at 13.00,

WP_09 - relative air moisture at 9.00,

WP_13 - relative air moisture at 13.00 ,

OP_09 - 24-hour sum of atmospheric precipitation at 9.00,

WS_09 - moisture content of litter at 9.00,

WS_13 - moisture content of litter at 13.00,

TP_09P - air temperature at 9.00 at forecast point,

WP_09P - relative moisture content of air at 9.00 at forecast point,

WP_13P - relative moisture content of air at 13.00 at forecast point,

WS_09P - moisture content of litter at the 9.00 at forecast point.

To enable drawing up a fire risk forecast (in the morning for the hours of the afternoon and the following day) formulae were calculated also enabling calculation of forecast moisture content of litter on the basis of its actual value and also current and forecast meteorological conditions. During analyses of the dependency of litter moisture content in the afternoon hours and the following day on its actual value and also on meteorological parameter values not included in the previously referred to data, used in forecasting meteorological parameter values based on a numerical weather model obtained from the Interdisciplinary Mathematical Modelling Centre of the University of Warsaw. The accepted principle was to achieve the highest possible verifiability of prognosis with maximal error tolerance amounting to $20 \%$ of actual value, for actual values of litter moisture content less than $40 \%$. Such an assumption guarantees appropriate calculation of litter moisture content for the extent of its moisture, at which the occurrence of fire is possible, so doing taking into consideration the possibility of a certain variation in moisture contents in the area of the whole zone. Similarly to the case of the previously described analysis for evaluation of the dependency between litter moisture in the hours of the afternoon and the following day on its actual value and meteorological parameters values used in multistep regression analysis, but in this instance the dependency was significantly greater (values of coefficient of determination from 0.52 to 0.83 ). On this basis formulae were drawn up enabling calculation of moisture content of litter both at the hour of 13.00 of the current day has also in the morning of the following day.

Moisture of litter forecast for the hour of 9.00 the following moisture_1_09 $=\mathrm{f}($ TP_09, OP_09, WS_09, WS_13_1, WS_09_A1, TP0_13, WP0_13, OP0_13, Z0_13, VW0_13, TP1_09, WP1_09, 
Moisture content of litter forecast for the hour 9.00 on the following day with regard to measurement data from the hour of 13.00

moisture_1_09_13 $=\mathrm{f}_{\left(\mathrm{TP} \_09\right.}$,WP_09, WS_09, TP_13, WP_13, WS_13, WS_09_A1, Z0_13, VW0_13, TP1_09, WP1_09, VW1_09)

Moisture content forecast for 13.00

moisture_0_13 = f $($ WP_09, OP_09, WS_09, WS_09_1, WS_13_1, TP0_13, WP0_13, OP0_13, Z0_13)

where:

TP_09 - air temperature at 9.00,

WP_09 - relative air moisture at 9.00,

OP_09 - 24-hour sum of atmospheric precipitation at 9.00,

WS_09- moisture content of litter at 9.00,

WS_09_1 - moisture content of litter at 9.00 the previous day,

WS_13_1 - moisture content of litter at 13.00 the previous day,

TP0_13 - air temperature forecast for 13.00,

WP0_13 - relative air moisture forecast for 13.00,

OP0 13 - sum of forecast precipitation at 13.00,

VW0 0 - 13 - wind speed forecast for 13.00,

WP_13 - relative air moisture at 13.00,

WS_09_A1 - average moisture content of litter at 9.00 for 4 successive previous days,

Z0_13 - cloudiness forecast for 13.00 ,

TP1_09 - air temperature forecast for the 9.00 on the following day,

WP1_09 - relative air moisture forecast for 9.00 the following day,

VW1_09 - wind speed forecast for 9.00 the following day,

TP_13 - air temperature at 13.00,

WS_13 - moisture content of litter at 9.00,

The basis of assessment of the proposed method was data concerning the frequency of occurrence of particular degrees of risk established according to tested methods, average number of fires in the zone in relation to the degree of risk and average surface area of fire at the given degree. These values for afternoon hours are shown in figure 3 and also in table 1.
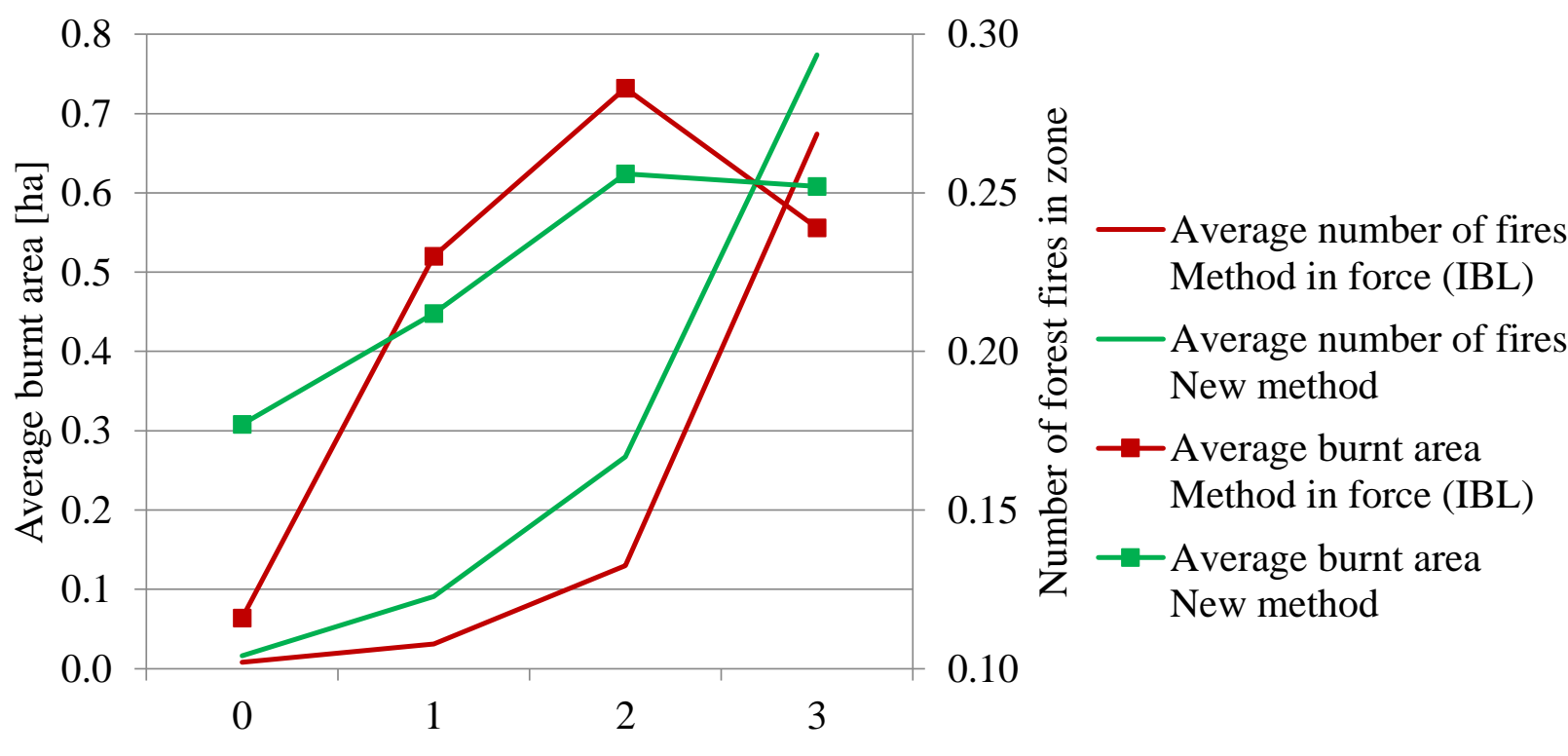

Forest fire risk degree 
Table 1. Presentation of data relating to forecast of forest fire risk at 13.00

\begin{tabular}{|l|l|l|r|r|r|r|}
\hline \multicolumn{2}{|c|}{} & \multirow{2}{*}{ unit } & \multicolumn{4}{|c|}{ Degree of risk } \\
\cline { 6 - 8 } & number of days with degree & & 0 & 1 & \multicolumn{1}{c|}{2} & \multicolumn{1}{c|}{3} \\
\hline \multirow{3}{*}{ IBL method } & item & 3075 & 2458 & 4524 & 3337 \\
\cline { 2 - 8 } & average number of fires & item & 0,008 & 0,031 & 0,130 & 0,674 \\
\cline { 2 - 8 } & average area of fire & ha & 0,116 & 0,230 & 0,283 & 0,239 \\
\hline \multirow{3}{*}{ New method } & number of days with degree & item & 4210 & 4133 & 3054 & 1997 \\
\cline { 2 - 8 } & average number of fires & item & 0,016 & 0,091 & 0,267 & 0,774 \\
\cline { 2 - 8 } & average area of fire & ha & 0,177 & 0,212 & 0,256 & 0,252 \\
\hline
\end{tabular}

On the basis of the data presented it is clearly seen that with the method in force in Poland a higher fire risk occurs significantly more frequently in comparison to the new method. Concerning occurrence of fires the increase in their numbers together with increased risk is clearer and more balanced for the new method. Significantly greater differences between degrees occur in the case of average fire areas. With the method in force the greatest area of fires, which occurred after 13.00 were at degree 3 . Reduction in this case of the area by 3 degrees might be connected with the conduct of extinguishing activity. If it concerns the relationship of surface area of fire to the degree established according to the tested method for afternoon hours, for the new method a clear increase of average area is visible from 0 to 2 degrees whereas the area at degree 3 is almost equal to the area at degree 2 . The analysis presented above clearly shows that the newly drawn up method enables significantly better definition of actual fire risk in comparison to the method currently applied.

The condition for appropriate forecasting of fire risk for the following day and the afternoon hours of the given day is precise calculation of envisaged moisture content of litter at those hours. The evaluation of accuracy performed for actual values less than $40 \%$ (with tolerance of margin of error amounting to $\pm 20 \%$ of actual value) of drawn up formulae enables obtaining accuracy at a level of $60 \%$ for forecasts in the morning for the following day and $70 \%$ for the afternoon of the current day. The schedule of forecast of litter moisture content values in relation to their actual values is shown in figures 4 and 5. 


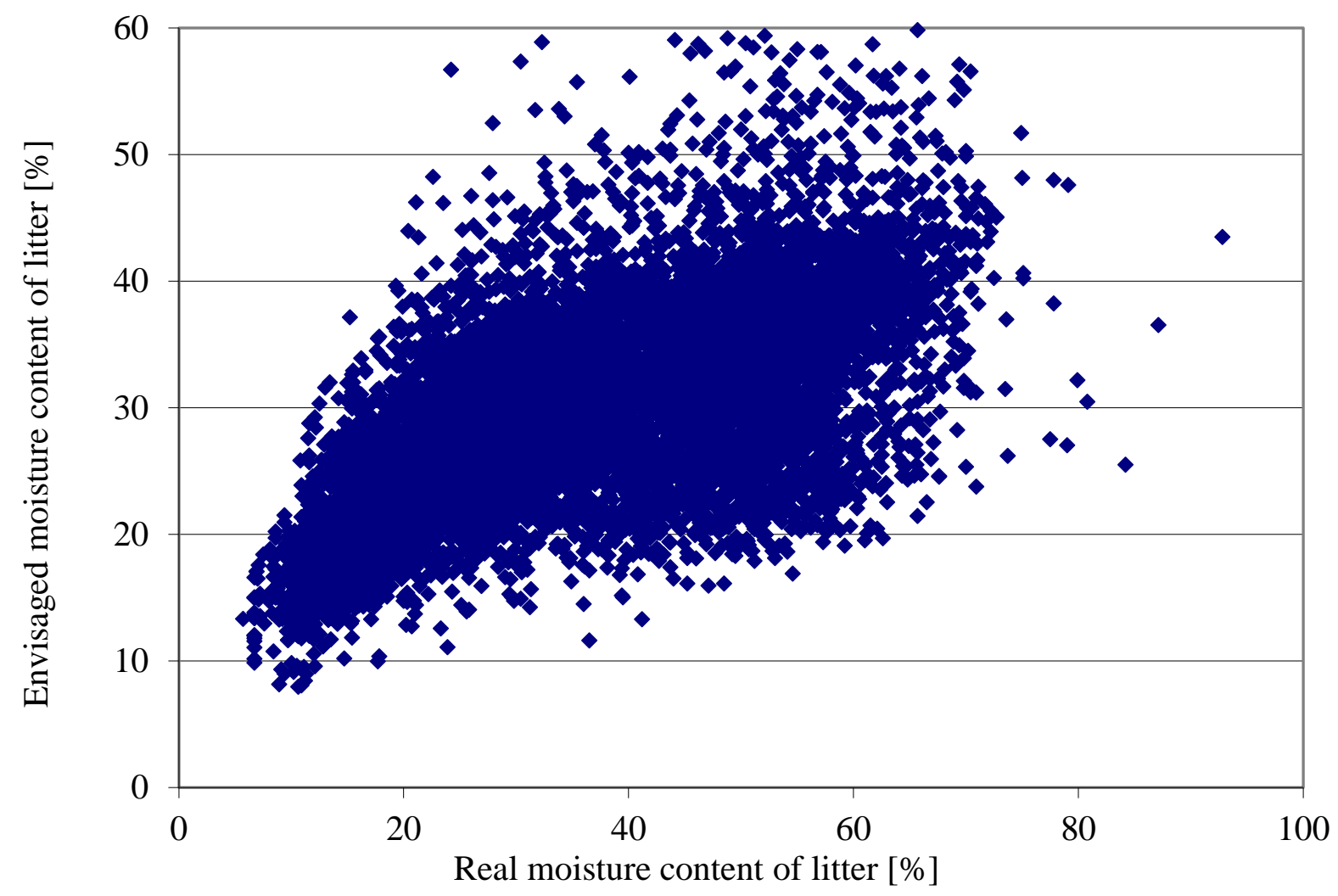

Figure 4. Schedule of litter moisture content forecast for 9.00 the following day

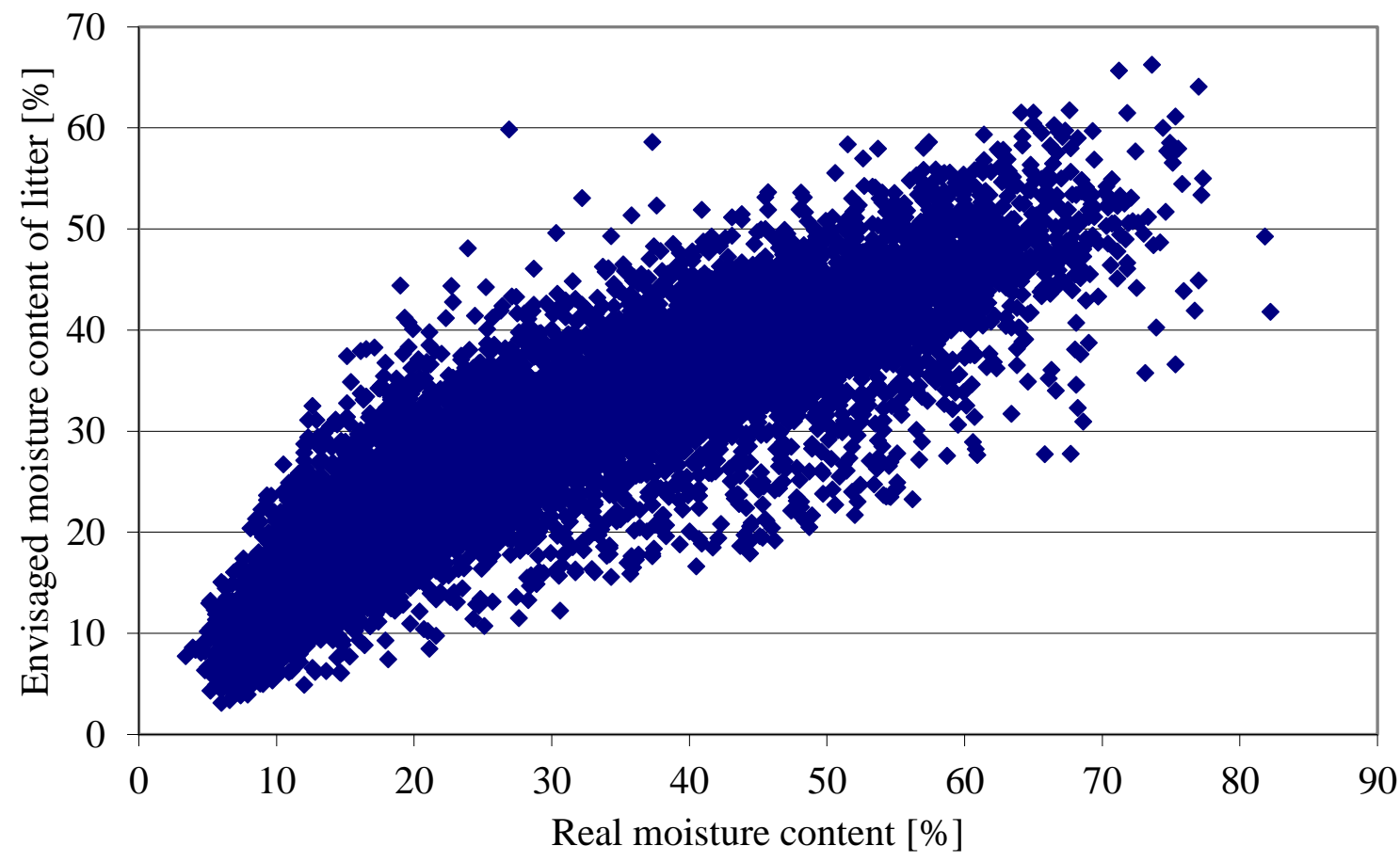

Figure 5. Schedule of litter moisture content forecast for 13.00

In the economic analysis of forest fire protection costs in relation to the applied method of forecasting forest fire risk, only those elements of the system are considered, which are operationally dependent on actual fire risk. This assessment is to a significant degree approximate, because it accepts identical costs for forestry areas counted to a specified category of fire risk. In the conduct of economic analysis 
it is accepted that particular activities in the extent of forest fire protection are performed in relation to the degree of risk. On this basis is calculated the cost of the operation of fire prevention protection with regard to affiliation of particular forestry administration areas to the forecast prognosis zones. It shows the possibility of obtaining, as a result of applying the new method, economies in the operation of the forest fire prevention system at a level of 10,000,000 PLN annually or approximately $30 \%$ of these costs.

\section{Summary}

The drawn up method is based on the measurement of the moisture content of inflammable material, which to a significant extent as an influence on its precision. The choice of test material - pine litter is appropriate to the specific characteristics of forest fires occurring in Poland. As a result of the work a forecasting method was successfully established enabling precise determination of fire risk in forests. The presented results obtained during testing of this method indicate great accuracy in forecasting forest fire risk and satisfactory accuracy of formulae enabling calculation of litter moisture content. On the basis of the entirety of the material presented in this study it may be stated that the drawn up method enables a decidedly better definition of the actual fire risk, simultaneously providing the possibility of its prognosis for later hours and should be introduced for application in forest fire protection. Such a solution may bring about significant limitation of forest fire prevention operating costs and facilitate the organisational work of the services responsible for forest fire protection. 